\title{
Pengaruh Media Kartu Kemudi Pintar Terhadap Hasil Belajar Siswa Pada Materi Sistem Ekskresi Manusia Di Kelas XI SMA Negeri 4 Batam TA. 2017/2018
}

\section{The Influence Of The Smart Steering Card Media To Student Learning Outcomes On Human Excretory System In Class High School 4 Batam Year 2017/2018}

\author{
Eva Carlina Pasaribu ${ }^{1}$, Rahmi $^{2 *}$ Notowinarto $^{3}$ dan Yarsi Efendi ${ }^{4}$ \\ ${ }^{1234}$ Program Studi Pendidikan Biologi, FKIP, Universitas Riau Kepulauan, Batam \\ *Koresponden: rahmikumbang@gmail.com
}

\begin{abstract}
Abstrak
Penelitian bertujuan untuk mengetahui pengaruh media kartu kemudi pintar terhadap hasil belajar pada materi sistem ekskresi siswa kelas XI SMAN 4 Batam Tahun Ajaran 2017/2018. Jenis penelitian quasi eskperimen dengan pendekatan Pretest-Posttest Control Group Design. Populasi penelitian adalah seluruh siswa kelas XI terdiri 5 kelas, sampel data dilakukan menggunakan cluster random sampling terdiri dari 2 kelas sampel yaitu sebagai kelas eksperimen dan sebagai kelas kontrol. Pengumpulan data menggunakan tes soal pilihan berganda untuk mengukur hasil belajar siswa, kemudian diolah untuk pengujian hipotesis dengan analisis chi-kuadrat, koefisien determinasi $\left(R^{2}\right)$ dan koefisien korelasi $(r)$. Hasil pengujian diperoleh tidak ada perbedaan nilai hasil belajar siswa kelas eksperimen maupun kelas kontrol, sedangkan nilai koefisien determinasi $\left(R^{2}\right)$ hanya sebesar $0.1123(11.23 \%)$ atau dengan nilai koefisien korelasi $(r)=0.335(3.35 \%)$, maka diperoleh kesimpulan tidak terdapat pengaruh media kartu kemudi pintar terhadap hasil belajar siswa dikelas XI SMA N 4 Batam.
\end{abstract}

Kata Kunci : Pengaruh, Media Kartu Kemudi Pintar, Hasil Belajar

\begin{abstract}
This study aims to determine the influence of smart steering card media to student learning outcomes on excretory system material in class XI MIA High School state 4 Batam Year 2017/2018. This research type is quasi experiment research. This research apply pattern Pretest-Posttest Control Group Design. The population in this study is all students of grade XI SMA N 4 Batam consisting of 5 classes, sampling is done by using cluster random sampling technique consisting of 2 class sample that is class as experiment class with control class. Data collection techniques used by test method multiple choice type to measure by student learning outcomes. Data analysis used was chi-square, coefficient of determination analysis and correlation of determination analysis. Based on the results of the hypothesis no differences between with student learning outcomes and obtained coefficient of determination $\left(R^{2}\right)$ for $0.1123(11,23 \%)$ or coefficient of determinati correlation on $(r)$ for $0.335(3.35 \%)$ then obtained the influence between Smart Steering Card Media on the learning can be concluded there is no influence of smart steering card media to student learning outcomes on class XI SMA N 4 Batam.
\end{abstract}

Keywords: The Influence, Smart Steering Card Media, Learning Outcomes

\section{PENDAHULUAN}

Pendidikan menjadi hal yang fundamental bagi kehidupan seseorang, dengan pendidikan yang baik maka akan baik pula pola pikir dan sikap seseorang. Makna Kurikulum yaitu perangkat mata pelajaran yang diberikan oleh suatu lembaga penyelenggara pendidikan yang berisi rancangan pelajaran yang diberikan kepeserta didik sehingga materi-materi kurikulum dapat mengarahkan pendidikan menuju arah dan tujuan yang menyeluruh (Djaali, 2004). Implementasi proses belajar Kurikulum 2013 dalam kelas 
siswa dituntut untuk lebih aktif dibandingkan guru yang hanya berfungsi sebagai fasilitator dengan peran dalam penguatan informasi materi yang dipelajari serta mendorong siswa agar berpikir kritis (Uno, 2011). Siswa juga dituntut untuk menguasai materi dan lebih banyak mencari tahu informasi berkaitan dengan materi yang dipelajari atau lebih menekankan pada proses pembelajaran aktif dengan 3 (tiga) aspek kompetensi, yaitu sikap (afektif), pengetahuan (kognitif), dan ketrampilan (psikomotorik). Tujuannya adalah memberi pengalaman belajar siswa dalam mengembangkan kompetensinya agar kelak mampu memahami dan menerapkannya dalam kehidupan sehari-hari.

Hasil observasi awal yang dilakukan peneliti berdasarkan wawancara bersama guru Biologi kelas XI ditemukan bahwa nilai hasil ulangan harian siswa cenderung belum mencapai presentase $85 \%$ yang tuntas. Salah satu penyebab rendahnya pencapaian siswa selama belajar, diduga hal ini disebabkan tidak adanya media pembelajaran yang efektif digunakan dalam proses belajar atau media yang dipakai oleh guru umumnyakurang memberikan rangsangan belajar seperti berupa; media power point, torso, alat-alat laboratorium penunjang praktikum, kurangnya diskusi dan sesi tanya jawab serta kecenderungan guru menjadi sumber informasi yang paling dominan dalam memberikan uraian tentang materi yang diajarkan.

Media pembelajaran merupakan komponen pembelajaran yang berguna untuk memperlancar interaksi guru dengan siswa (Hasan dan Susilowibowo, 2015) . ketika siswa terlibat secara aktif, baik fisik, mental maupun sosial dalam pembelajaran, di sampin menunjukkan semangat belajar yang tinggi dan rasa percaya diri maka dapat dikatakan bahwa pembelajaran tersebut berhasil. ( Fitriana et al., 2014). Media Kartu Kemudi Pintar (KKP) memiliki banyak kelebihan yakni praktis, mudah dibuat dan lebih meningkatkan pemahaman peserta didik dalam materi yang akan diajarkan (Djamariah dan Syaiful, 2002). Memang pada saat ini opini sebagian siswa menganggap bahwa mata pelajaran biologi adalah pelajaran yang terbilang sulit, seperti pokok bahasan sistem ekskresi manusia dikarenakan banyaknya istilah yang harus dihafal dan pengertian yang harus dipahami dalam proses setiap bagian organ tertera dalam materi tersebut. Sehingga tidak sedikit siswa mengalami kesulitan belajar dan berdampak pada hasil belajar siswa. Secara umum media KKP mempunyai karakteristik dapat memperjelas pemahaman dan dapat mengatasi keterbatasan ruang, tempat dan waktu (Rahadi, 2004). Sehingga berdasarkan hal tersebut, peneliti ingin mencoba mengaplikasikan suatu media pembelajaran yaitu Kartu Kemudi 
Pintar (KKP) yakni berbasis media yang inovatif dan kreatif sebagai penunjang proses pembelajaran dan evaluasi hasil belajar (Ristyani, 2013). Tujuan adalah untuk melihat sejauh mana pemahaman siswa terhadap materi yang akan disampaikan tersebut.

\section{METODE PENELITIAN}

Penelitian ini telah dilaksanakan di SMA Negeri 4 Batam di Kelas XI. Waktu penelitian dilakuan selama 3 (tiga) bulan. Jenis penelitian ini termasuk quasi experimental (eksperimen semu) yakni dengan desain yang mempunyai kelompok kontrol yang dapat berfungsi sepenuhnya untuk mengontrol variabel diluar yang mempengaruhi pelaksanaan eksperimen serta dapat menggeneralisasi kualitas dan karakteristik tertentu yang ditetapkan oleh peneliti (Sundayana, 2014)

Populasi pada penelitian ini mencakup seluruh siswa kelas XI MIA yang berjumlah 208 siswa dan terbagi menjadi 5 (lima) kelas. Penelitian menerapkan desain Pretest-Posttest Control Group Design. Pengambilan sampel menggunakan Probability Sampling dengan pendekatan yang dipilih yaitu Cluster Random Samplinguntukmenentukan sampel objek yang akan diteliti dipilih secara acak, yakni dengan sampel adalah kelas XI MIA1 sebagai kelas eksperimen dan XI MIA 5 sebagai kelas control (Tabel 1).

Tabel 1. Pretest-Posttest Control Group Design (Sudijono, 2009)

\begin{tabular}{|c|c|c|c|}
\hline Kelompok & Pretest & Perlakuan & Postest \\
\hline Eksperimen & Y1 & X1 & Y2 \\
\hline Kontrol & Y1 & X2 & Y2 \\
\hline
\end{tabular}

Keterangan : X1: Perlakuan dengan Media Kartu Kemudi Pintar; X2: Perlakuan dengan Media Power Point; Y1: Tes awal yang sama pada kedua kelompok; Y2: Tes akhir yang sama pada kedua kelompok

Pengumpulan data adalah merupakan data hasil belajar siswa yaitu pretest dan posttest. Instrumen yang digunakan untuk mengukur hasil belajar siswa yaitu berupa butir-butir soal tipe pilihan berganda (multiple choice). Tes hasil belajar yang digunakan berupa soal pilihan berganda (multiple choice) dengan 5 pilihan jawaban (a,b,c,d, dan e) skor untuk item diberikan dengan 1 (bagi item yang benar) dan 0 (item yang dijawab salah) (Arikunto, 2009; Sudaryono, $d k k$. 2012). Analisis instrumen dengan menggunakan uji validitasmenggunakan rumus korelasi product moment, uji reliabilitas dengan rumus Kuder-Richardson 20 (KR-20) dan tingkat kesukaran soal dan daya pembeda soal (Djaali, 2004; Misbahuddin \& Iqbal, 2013; Sundayana, 2014). Data utama yang diperoleh selanjutnyadianalisis dengan melakukan Uji normalitas 
menggunakan rumus chi-kuadrat, Uji homogenitas dengan uji-fisher atau uji varian serta analisis koefisien determinasi atau berdasarkan analisis regresi linear sederhana dan Uji N-gain skoruntuk mengetahui apakah terjadi peningkatan hasil belajar siswa pada kelas eksperimen atau tidak (Sudijono, 2009).

\section{HASIL DAN PEMBAHASAN}

Uji pendahuluan terhadap angket instrumen yang diuji coba ke kelas diluar kelas sampel hasil sebagai berikut: a) Uji Validitas Soal, dengan hasil terdapat 30 soal atau sebesar $60 \%$ yang dinyatakan valid dan $40 \%$ dinyatakan tidak valid. Soal yang valid dikatakan layak untuk digunakan sebagai instrumen soal di kelas sampel penelitian; b) Uji Realibilitas Soal, hasil menunjukkan nilai koefisien korelasi berada pada nilai interval 0,8-1,0, sehingga hasil reliabilitas tes tersebut memiliki kriteria sangat tinggi; c) Uji Tingkat Kesukaran Soal, hasil perhitungan menunjukkan 30 soal tersebut termasuk dalam nilai kriteria 0,31-0,70 pada kategori tingkat kesukaran soal yang sedang atau cukup; dan d) Uji Daya Pembeda Soal diperoleh 24 butir soal atau sebesar 80\% memiliki daya pembeda baik, dan 6 soal atau sebesar 20\% memiliki daya pembeda cukup serta tidak terdapat soal dengan kategori baik sekali, jelek, maupun negatif yang harus dibuang. Deskripsi hasil belajar siswa yang diperoleh dari nilai Pretest di Kelas Eksperimen dan Kontrol dapat disajikan pada Tabel 2.

Tabel 2. Data Hasil Pretest Kelas Eksperimen dan Kontrol

\begin{tabular}{ccc}
\hline DATA & KELAS EKSPERIMEN & KELAS KONTROL \\
\hline Total & 2718 & 2832 \\
Nilai Tertinggi & 86 & 83 \\
Nilai Terendah & 50 & 43 \\
Rata-rata & 66.29 & 67.43 \\
\hline
\end{tabular}

Berdasarkan data hasil pretest diatas sebagai berikut: Di kelas eksperimen jumlah siswa sebanyak 41 orang, total nilai hasil belajar yang diperoleh $(\Sigma)$ sebesar 2718, nilai tertinggi siswa (Max) adalah 86 dan nilai terendah (Min) adalah 50 atau memiliki rentang nilai (r) sebesar 36 dengan siswa yang memenuhi nilai KKM sebanyak 13 orang (32\%) tuntas dan tergolong tidak tuntas sebanyak 28 orang (68\%) atau dapat disimpulkan bahwa hasil belajar pretest yang tergolong tidak tuntas. Sedangkan hasil pretest siswa di kelas kontrol nilai tertinggi siswa (Max) adalah 83 dan nilai terendah (Min) adalah 43, median (Me) sebesar 70 dan nilai modus (Mo) sebesar 70 serta dengan nilai rata-rata 67.43 dengan siswa yang 
memenuhi nilai KKM sebanyak 26 orang (61\%) dan tidak tuntas sebanyak 19 orang (31\%) serta disimpulkan bahwa pretest siswa kontrol tuntas. Hasil belajar siswa dari hasil nilai posttest di kelas eksperimen dan kontrol dapat disajikan pada sebagai berikut Tabel 3.

Tabel 3. Data hasil Posttestdi Kelas Eksperimen dan Kontrol

\begin{tabular}{ccc}
\hline DATA & KELAS EKSPERIMEN & KELAS KONTROL \\
\hline Total & 3349 & 3279 \\
Nilai Max & 93 & 90 \\
Nilai Min & 70 & 53 \\
Rata-rata & 81.68 & 78.07 \\
\hline
\end{tabular}

Berdasarkan data hasil posttest diatas pada kelas eksperimen, total nilai hasil belajar yang diperoleh $(\Sigma)$ sebesar 3349, nilai tertinggi siswa (Max) adalah 93 dan nilai terendah (Min) adalah 70 atau memiliki rentang nilai (r) sebesar 23 dengan siswa yang memenuhi nilai KKM sebanyak 37 orang $(88 \%)$ tuntas dan tergolong tidak tuntas sebanyak 4 orang (12\%) atau dapat disimpulkan bahwa hasil belajar posttest yang tergolong tuntas. Sedangkan hasil posttest siswa di kelas kontrol nilai tertinggi siswa (Max) adalah 90 dan nilai terendah (Min) adalah 53, jumlah skor keseluruhan 3279 dengan nilai rata-rata dari hasil Posttest adalah 78.07dengan siswa yang memenuhi nilai KKM sebanyak 35 orang (83\%) dan tidak tuntas sebanyak 7 orang (17\%) serta dapat disimpulkan bahwa posttest siswa kontrol tuntas sama dengan kelas eksperimen

Analisis lebih lanjut yakni uji prasyarat data sebagai berikut: a) Perhitungan uji normalitas: nilai pretest nilai $\mathrm{X}^{2}{ }_{\text {hitung }}=7.615$ untuk kelas eksperimen dan nilai $\mathrm{X}^{2}{ }_{\text {hitung }}$ kelas kontrol 7.0423 serta $X^{2}$ tabel $=11,070(\alpha=5 \%)$ dengan kriteria pengujian yang digunakan apabila $\mathrm{X}^{2}$ hitung $\leq \mathrm{X}^{2}$ tabel maka dapat dinyatakan bahwa data nilai pretest dari kedua kelas tersebut berdistribusi normal. Selanjutnya analisis data nilai posttest untuk kelas eksperimen dan kontrol yang di peroleh $X^{2}{ }_{\text {hitung }}=9.898$ dan $X^{2}{ }_{\text {hitung }}=6.610$ serta $X^{2}$ tabel $=11,070(\alpha=5 \%)$ maka dengan kriteria pengujian $X^{2}$ hitung $\leq X^{2}$ tabel dinyatakan berdistribusi normal. Data nilai pretest maupun posttestdari kedua kelas tersebut berdistribusi normal; b) Hasil Uji Homogenitas, untuk pretest untuk kedua kelas sampel diperoleh $F_{\text {hitung }}=1.133$ dan $F_{\text {tabel }}$ $(\alpha=0.05)(40: 41)=1.685$ sehingga $F_{\text {hitung }} 1.133<\mathrm{F}_{\text {tabel }} 1.685$ maka dapat disimpulkan bahwa kedua kelompok tergolong homogen. Sedangkan hasil uji posttest untuk kedua kelas sampel diperoleh $F_{\text {hitung }}=1.608$ dan $F_{\text {tabel }(\alpha=0.05)(40: 41)}=1.685$ sehingga $F_{\text {hitung }} 1.608<F_{\text {tabel }} 1.685$ maka dapat disimpulkan bahwa kedua kelompok tersebut tergolong homogen. 
Pengujian hipotesis yang dilakukan antara media kemudi pintar terhadap hasil belajar menggunakan pendekatan analisis nilai koefisien determinasi $\left(R^{2}\right)=0,335$ dan nilai koefisien korelasi $(r)=0.1123$ atau $11,23 \%$. Hasil tersebut menunjukkan bahwa media kartu kemudi pintar (KKP) terhadap hasil belajar siswa hanya memberikan konstribusi yang menunjukkan nilai relatif rendah atau tidak memberikan pengaruh $(\mathrm{r}=11,23 \%)$. Sedangkan perhitungan Ngain skor kelas eksperimen dan kelas kontrol sebagai berikut; nilai rata-rata N-gain kelas eksperimen sebesar 0.557 pada katagori sedang, sedangkan hasil $\mathrm{N}$-gain kelas kontrol berada pada kategori sedang yaitu sebesar 0.471. Berdasarkan nilai data tersebut menunjukkan bahwa peningkatan hasil belajar dikelas eksperimen lebih besar dibandingkan kelas control (Tabel 4). Tabel 4. Perhitungan N-Gain Kelas Eksperimen dan Kelas Kontrol

\begin{tabular}{ccc}
\hline N-Gain & Kelas Eksperimen & Kelas Kontrol \\
\hline Tertinggi & 1.000 & 1.000 \\
Terendah & 0.000 & 0.000 \\
Rata-rata & 0.557 & 0.471 \\
Kategori & Sedang & Sedang \\
\hline
\end{tabular}

Pembahasan Data hasil pretest siswa pada materi sistem ekskresi menunjukkan bahwa hasil rata-rata dikelas eksperimen lebih kecil dengan nilai yang tidak berbeda jauh dibandingkan kelas control, hal ini dikarenakan belum diberi perlakuan pada saat proses pembelajaran dan merupakan tahap awal untuk melihat seberapa jauh pengetahuan awal siswa terhadap materi yang akan disampaikan. Pada hasil uji ini terungkap ada beberapa indikator soal yang sulit untuk dijawab oleh para siswa, seperti indikator soal mendeskripsikan proses ekskresi yang berlangsung pada setiap fungsi dari organ, mengidentifikasi struktur jaringan penyusun dan menganalisis gangguan serta penyakit pada sistem ekskresi manusia dalam kehidupan sehari-hari. Salah satu penyebabnya dikarenakan belum diberikannya materi secara mendalam kepada siswa sehingga sebagian siswa mengalami kesulitan dalam mengerjakan soal. Sedangkan hasil Posttest dilakukan setelah proses pembelajaran selesai yang diberi perlakuan dengan metode pembelajaran berbeda pada kedua kelas, diperoleh nilai rata-rata hasil belajar yakni dengan menggunakan media kartu kemudi pintar (KKP) pada kelas eksperimenlebih tinggi dari pada nilai rata-rata dengan menggunakan media pembelajaran power point di kelas kontrol.

Kondisi diatas dapat terjadi karena telah terjadi perubahan perilaku siswa saat belajar di kelas muncul sebagai reaksi terhadap proses pembelajaran yang sedang berlangsung di kelas 
tersebut yang dipengaruhi oleh banyak faktor. Karwati dan Priansa (2014) dalam (Putri et al., 2016) menyatakan bahwa beberapa faktor internal yang mempengaruhi hasil belajar belajar siswa diantaranya ciri khas/karakteristik siswa, sikap atau perilaku terhadap belajar, motivasi belajar, konsentrasi belajar, mengolah bahan belajar, menggali hasil belajar, rasa percaya diri dan kebiasaan belajar. Perbedaan hasil belajar diperkuat oleh penelitian yang dilakukan (Sari et $a l ., 2017)$ yang menyatakan ada pengaruh yang lebih baik dengan menggunakan media kartu kemudi pintar terhadap hasil belajar siswa dibandingkan dengan pembelajaran dengan menggunakan media konvensional yang digunakan. Adapun beberapa indikator soal yang sulit dijawab oleh siswa akhirnya dapat terjawab, hal ini terjadi karena pemberian materi sistem ekskresi secara mendalam dengan metode KKP sudah baik diberikan kepada siswa.

Media kartu kemudi pintar (KKP) adalah salah satu media pembelajaran yang merupakan suatu alat bantu pembelajaran yang berguna untuk mengingat materi dan dapat membantu meningkatkan hasil belajar siswa (Sari, et. al., 2017). Penggunaan media kartu kemudi yang diaplikasikan dikelas eksperimen. Didalam prosesnya terlihat siswa aktif dalam mengikuti pembelajaran, siswa aktif dalam menjawab pertanyaan yang telah disajikan melalui kartu pintar. Berdasarkan hasil penelitian dapat dinyatakan bahwa Media Kartu Kemudi Pintar merupakan bahasa komunikasi guru dalam pembelajaran dapat memberikan kesempatan bagi siswa untuk terlibat langsung dalam pembelajaran.

Kendala yang ditemukan dalam proses pembelajaran muncul dikarenakan adanya beberapa faktor yang mampu mempengaruhi proses belajar siswa yaitu minat dan motivasi yang berpengaruh besar terhadap proses belajar siswa disekolah. Seseorang yang memiliki motivasi yang tinggi akan menghasilkan jiwa yang semangat untuk belajar (Sumantri, $d k k$. 2007; Sundayana, 2014). Selain itu, faktor kelelahan juga dapat mempengaruhi hasil belajar yaitu kelelahan jasmani serta kelelahan rohani dapat dilihat adanya kelesuan dan kebosananan pada saat proses pembelajaran berlangsung. Hal ini terjadi dikarenakan siswa yang memiliki waktu jam pelajaran yang padat sehingga minat dan motivasi untuk belajar sudah hilang (Sujana, 2010; Putri et al., 2016).

Selain itu, dari media itu sendiri dalam penggunaannya adalah pengaturan waktu dari siswa yang masih mengalami kesulitan untuk menyelesaikan permasalahan dalam media dan daya keaktifan siswa didalam kelompok yang berbeda-beda. Sehingga akan kurang baik bila digunakan pada siswa yang malas berpikir. Hal ini sejalan dengan penelitian yang 
dilakukan (Ristyani, 2013) yang menyatakan media kartu kemudi pintar dapat mempengaruhi hasil belajar siswa. Apabila diberi perbandingan dengan metode yang lain, seperti metode Card Sort dapat mengoptimalkan pemahaman siswa pada mata pelajaran Biologi artinya metode Card Sort dapat memberikan penjelasan tentang materi yang diberikan guru kepada siswa sehingga siswa menjadi mengerti dengan apa yang sedang dan telah dipelajarinya. Dengan begitu aktivitas belajar guru dan siswa semakin baik dan tentunya akan diiringi oleh hasil belajar yang baik pula serta sangat menyenangkan semua pihak.

Media kartu pintar yang merupakan bahasa komunikasi guru dalam pembelajaran dapat memberikan kesempatan bagi siswa untuk terlibat langsung dalam pembelajaran dan memungkinkan terjadinya komunikasi multi arah. Komunikasi multi arah merupakan komunikasi yang terjadi antara guru dengan siswa yang memberikan respon dengan siswa lain yang terlebih dahulu memberikan respon. Adanya komunikasi multi arah, menunjukkan bahwa siswa aktif pada saat pembelajaran (Windiastuti, 2014). Menurut Sari (2017) hasil belajar menggunakan media kartu pintar telah mencapai ketuntasan KKM yaitu 76,875. Sedangkan menurut Qurniawati et al., (2013) kenaikkan prestasi belajar aspek kognitif kelas eksperimen $(59,5000)$ lebih tinggi dari rata-rata selisih nilai postest dan pretest aspek kognitif kelas kontrol $(52,6786)$.

\section{KESIMPULAN}

Terdapat hubungan yang relatif rendah antara Media Kartu Kemudi Pintar (KKP) terhadap hasil belajar siswa kelas XI MIA SMA N 4 Batam, tetapi memberikan pengaruh positip atas peningkatan hasil belajar siswa. Media kartu kemudi pintar (KKP) dapat dijadikan referensi pembuatan media namun perlu disesuaikan dengan materi yang akan di ajarkan .

\section{REFERENSI}

Arikunto, S., 2009. Dasar-dasar Evaluasi Pendidikan. Bumi Aksara. Jakarta.

Djaali, 2004. Pengukuran dalam bidang pendidikan. Universitas Negeri Jakarta (UNJ). Jakarta.

Djamariah dan Syaiful, B., 2002. Strategi Belajar Mengajar. Rineka Cipta. Jakarta.

Fitriana, I., Mulyani, S., dan Mulyani, B., 2014. Peningkatan Aktivitas dan Hasil Belajar Siswa Melalui Model Pembelajaran Activity Based Learning Berbantuan Flash Card Dilengkapi LKS pada Materi Isomer dan Reaksi Senyawa Hidrokarbon Kelas X SMA 
Batik 1 Surakarta Tahun Pelajaran 2012/2013. Jurnal Pendidikan Kimia, Vol. 3(2): 88-95.

Hasan, I., dan Susilowibowo, J. 2012. Pengembangan Kartu Pintar Sebagai Media Pembelajaran Materi Pokok Pengaruh Transaksi Keuangan Terhadap Perubahan Akun-akun di SMK Negeri 1 Ngawi. Jurnal Pendidikan Akuntansi (JPAK) Vol 3 (2): $1-10$

Misbahuddin, \& Iqbal, H., 2013. Analisis Data Penelitian Dengan Statistik. Bumi Aksara. Jakarta.

Putri, R, B., Notowinarto, \& Agustina, F., 2016. Antara Perilaku Siswa Saat Belajar Di Kelas Dengan Hasil Belajar Biologi Pada Pokok Bahasan Keanekaragaman Hayati Siswa Kelas X SMA Negeri 14 Batam. Simbiosa, 5(1): 25-23.

Qurniawati, A., Nugroho, A. dan Saputro, C., 2013. Efektivitas Metode Pembelajaran Kooperatif Tipe Numbered Head Together (NHT) dengan Media Kartu Pintar dan Kartu Soal Terhadap Prestasi Belajar Siswa Pada Materi Pokok Hidrokarbon Kelas X Semester Genap SMA Negeri 8 Surakarta Tahun Pelajaran 2012/2013. Jurnal Pendidikan Kimia, 2(3):166-174.

Ristyani, A., 2013. Peningkatan Motivasi Belajar Matematika Melalui Media Kartu Kemudi Pintar Pada Siswa Kelas V di Sekolah Dasar Muhammadiyah II Surakarta Tahun Pelajaran 2012/2013. [Skripsi]. Pendidikan Guru Sekolah Dasar, Fakultas Keguruan Dan Ilmu Pendidikan, Universitas Muhammadiyah Surakarta. Surakarta.

Rahadi A., 2004. Media Pembelajaran. Departemen Pendidikan Nasional. Jakarta.

Sari, Y. A., Bahar, A., \& Rohiat, S., 2017. Studi Perbandingan Pembelajaran Kooperatif Menggunakan Media Kartu Pintar Dan Kartu Kemudi Pintar. Jurnal Alotrop: Pendidikan Kimia Dan Ilmu Kimia, 1(1): 44-48.

Sudaryono, Margono dan Rahayu, 2012. Pengembangan Instrumen Penelitian Pendidikan. Graha Ilmu. Yogjakarta.

Sudijono, A., 2009. Pengantar Statistik Pendidikan. Raja Grafindo Persada. Jakarta.

Sujana, N., 2010. Penilaian Proses Hasil Belajar Mengajar. PT Remaja Rosdakarya. Bandung.

Sumantri, Mulyani dan S. Nana, 2007. Perkembangan Peserta Didik. Cetakan Ke-II. Universitas Terbuka. Jakarta.

Sundayana, R., 2014. Statistika penelitian pendidikan. Alfabeta. Bandung.

Uno, H. B. 2011. Model Pembelajaran: Menciptakan proses belajar mengajar yang kreatif dan efektif. Bumi Askara. Jakarta.

Windiastuti, E. P., 2014. Pengembangan Media Permainan Kartu Pintar Pada Pembelajaran IPA Materi Kelompok Tumbuh-Tumbuhan di SMP. Jurnal Pendidikan Sains. Vol. 02 (2):300-307. 